\title{
Assessment of Domestic Wastewater Disposal in Some Selected Wards of Maiduguri Metropolis, Borno State, Nigeria
}

\author{
Abba Kagu ${ }^{1}$, Hauwa Lawan Badawi ${ }^{2} \&$ Jimme M. Abba $^{1}$ \\ ${ }^{1}$ Department of Geography, University of Maiduguri, Nigeria \\ ${ }^{2}$ National Commission for Museums and Monuments, Maiduguri, Nigeria \\ Correspondence: Abba Kagu, Department of Geography, University of Maiduguri, Maiduguri, Nigeria. Tel: \\ 234-803-716-8161. E-mail: elbadawis1@yahoo.com
}

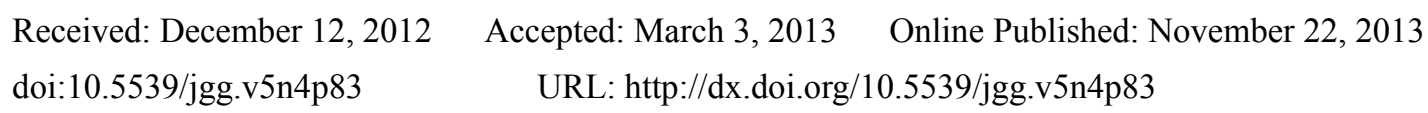

\begin{abstract}
This study evaluates domestic wastewater disposal in some selected wards of urban Maiduguri. The unprecedented population growth in Maiduguri generally is directly proportional to its demand for water supply for both domestic and industrial needs. Consequently the more water is consumed, the more its waste is generated. This in turn encourages its indiscriminate disposal particularly in an environment with poor drainage system such as most parts of Maiduguri urban area. It is against this background that the study examined how domestic wastewater is disposed in Maiduguri using the following objectives: to quantify the amount of domestic wastewater generated in the sampled areas, to study and describe the methods used in disposing wastewater, and to highlight the issues due to poor drainage in the town. The scope therefore, covers only domestic wastewater disposal in the selected wards with reference to individual household wastewater disposal system. This was based on planned and unplanned drainage system areas. New G R A and Bulumkutu were selected as the combination of the planned and unplanned areas, Hausari as unplanned and Gwange as planned areas respectively. Purposive, stratified and accidental sampling methods were employed at different stages in the sampling of the wards and the respondents. Three hundred and sixty copies of questionnaire designed to capture the objectives of the study were administered in the three selected wards (120 for each ward). The data obtained were analyzed using simple descriptive statistic and ANOVA. From the results obtained, the mean responses of the residents with regard to the wastewater generated from bathing, washing, food preparation and others, Maisandari has the highest values: $2.1583^{\mathrm{a}}, 1.3417^{\mathrm{a}}, 1.1250^{\mathrm{a}}$ and $1.1250^{\mathrm{a}}$ at 0.05 significant levels. This implies that most of the wastewater generated in the study area came from Maisandari ward. As a result of the serious environmental and health implication of this indiscriminate wastewater disposal in the study area, it is therefore recommended, that Borno State government should ensure effective/efficient maintenance of the existing waste disposal system and those areas without adequate drainage system should be provided by the government. The State government should provide drainages in the urban which are channelized in to central outlet system where it can be easily treated before final disposal for other uses.
\end{abstract}

Keywords: environment, health, waste water, disposal, drainages and maiduguri

\section{Introduction}

\subsection{Background to the Study}

Water is one of the basic necessities for human survival, but the uses of water leads to generation of its output which is wastewater. Karen (2008) pointed out that, of all the planets in the solar system, Earth is the only planet known as "the water planet". However, the larger part of its human population either suffers lack of adequate potable water supply or mismanages the little within their reach most especially in the urban areas. Ross (1972) asserts that, water uses generally range from domestic, industrial to agricultural purpose. In the urban areas for instance, the water use are more of domestic and industrial activities, as such, large quantity of wastewater is generated with its serious problem of disposal on the environment and the health of people. According to Karen (2008) therefore, wastewater could simply be referred to as "water that contains waste from homes or industries". This confirms with the assertion of Brower and Ende (1990) that wastes from water could be attributed largely to sewage which consists of human waste, other organic wastes and detergents. From the views of these scholars, domestic wastewater could be referred to as all kinds of water generated as aftermath of water usage from bathing, washing and food preparation at home. 
In Borno State for instance, most of the population is concentrated in Maiduguri and this is not unconnected with the fact that Maiduguri is the state capital, as most of the infrastructural facilities are located in its confinement. As a result of this and coupled with the lack of monitoring of urban development and poverty, gross environmental mismanagement set-in with serious consequences on human health and environmental quality. Wastewater generation and its improper disposal then becomes one of such environmental problems in Maiduguri, paving ways to distortion of its environment and posing health threats. The open disposal of wastewater provides convenient ground for breeding germs, disease vectors and an eye sore with offensive odour. This is affirmed by Pink (2006) who stated that, as a result of improper wastewater disposal in most cities in the developing countries, larger proportion of their population are exposed to varied forms of diseases that are claiming lives and distorting their scenery.

However, in the developed countries, wastewater generated is disposed off through centralized channel facilities where they are treated and recycled for effective water management. Whereas, in developing countries most of the urban settlements were either not effectively planned or not served with effective wastewater disposal facilities (Karen, 2008). From this assertion Maiduguri metropolis could be termed as one of such urban areas found in the developing countries. In this urban, effective wastewater management facilities are not available as such wastewater was either allowed to flow freely into open space or into poorly constructed drainage network.

\subsection{Statement of the Problem}

Maiduguri with the population 733,176 , as at 2007 , has the highest number of people in terms of population compared with the local government areas in the state (NPC, 2007).This dynamic population of Maiduguri is directly proportional to its demand for water supply for both domestic and industrial needs by the residents. Consequently, the consumption of water equally leads to wastewater generations and disposal which are most of the time done without environmental consciousness. Generally, wastewater is generated from various points ranging from homes, hospitals, markets to industries. In most of the wards in Maiduguri, it is common to see wastewater being disposed off indiscriminately in open spaces and uncontrolled evacuation gutters and soak- away. All these actions are not without their implication on the health of the residents and their environmental quality. This is because improper wastewater disposals serve as the breeding ground for disease vectors such as mosquitoes, flies and other organisms. The sight of this wastewater equally distorts the beauty scenery of the environment, block road or path and generates offensive smell or odour. Bulunkutu, Gwange and Hausari wards in Maiduguri for instance were among the worst hit wards where the indiscriminant wastewater disposal is encouraged due to lack of good drainage network. It is against this background that the study was necessitated particularly in these wards as there was limited study that captured assessment of domestic wastewater disposal particularly in the effected wards mentioned (Gwange, Hausari and Maisandari wards) so as to suggest effective ways of managing the wastewater in the area.

\subsection{Aim and Objectives}

The aim of this study is to examine the disposal of domestic wastewater in some selected wards of Maiduguri. To do this, the study intends to achieve the following specific objectives:

i. Quantify the amount of domestic wastewater generated in Gwange, Hausari and Maisandari wards.

ii. Study and describe the methods used in disposing wastewater.

iii. Highlight the issues due to poor drainage in the town.

\section{Literature Review}

Wastewater is defined in so many ways by different authors. UNEP (2010) viewed Wastewater as any water that has been adversely affected in quality by anthropogenic influence. It comprises liquid waste discharged by domestic residences, commercial properties, industry and/or agriculture and can encompass a wide range of potential contaminants and concentrations. According to Larry (2002) wastewater is the water that has been used and is no longer needed for any other particular purpose.

The population of people in households or areas contributes to domestic wastewater generation and disposal in places with enough water supply (Kenneth, 1993). For example a household of ten persons will use more water than that of three or four persons, consequently, the generation of wastewater will be more in the household with many persons, wards and areas with high population densities also generate more wastewater than areas of less population. This was supported by Mollison (1998) that the disposal of wastewater especially in urban areas of both developed and developing countries is a problem that continues to grow with development of nations and growth of population. The demand and uses of modern facilities increase the rate of wastewater disposal. In areas and homes with more facilities and high demand for water, wastewater disposal tends to be high 
(httpldomesticldisposal|wastewater $\backslash h t m$ ). Wastewater disposal can also be influenced by quantity or volume of water discharged by a dwelling or household. Hammer (1977) stated that the volume of wastewater from residential areas vary depending on the type of dwelling. Large flows come from family houses that have several bathrooms, automatic washing machine and other water using appliances. Availability of disposal systems is a factor that affects wastewater disposal.

Oluwande (1971) stated that "collection of wastewater is best achieved by a full sewage system". If there is no sewage disposal or transportation system, wastewater will be disposed off anyhow. This could be either by free throw into water bodies which are harmful to human and animals and equally pollute the environment. Some drainage networks are not properly maintained and such leads to their blockage either by sand, refuse or stones.

UNEP (2010) stated that, in terms of wastewater disposal, in Africa about 80\% of water consumption of those connected to the sewer ends up discharged into the municipal sewer. For instance in semi-arid and drought prone Gaborone the return flow is $50-65 \%$ thus, if poor people are connected in great numbers, the resultant reduced sewer flows could upset the operation of the sewer system because of the little water being used to keep waste flowing. He added in Lagos, wastewater is discharged to the Lagos lagoon and even sullage (grey water) water is discharged in open drain, throughout some of the urban catchments. Again in the largest peri urban settlement of Nairobi known as Kibera, drainage is virtually non-existent and during the rains in April/May and December, the areas are hardly accessible due to storm water and sullage nuisance.

In ideal situation the sewage is channeled or piped out of cities for treatment. Bulk of sewage contains water as the main component while other constituents include organic wastes and chemicals. Sewage water pollution is one of the major problems in cities. This is because; sewage water is drained off into rivers without treatment. Careless disposal of sewage water leads to a chain of problems such as spreading of diseases, euthrophication, increase in BOD etc (www.buzzle.com).

Considering the magnitudes of the effect or impact of wastewater, over 8 million people on the planet, disposing of sewage waste is a major problem. In developing countries, many people still lack clean water and basic sanitation (hygienic toilet facilities) sewage disposal affects people's immediate environments and leads to water-related illnesses such as diarrhea that kills 3-4 million children each year (According to WHO, water-related diseases could kill 135 million people by 2010). Moreover, an estimated 700 million people have no access to proper toilet and 1,000 Indian children die of diarrhea sickness every day (The Economist, 2008). Some 90\% of China's cities suffer from some degree of water pollution (Chinadaily.com, 2005) and nearly 500 million people lack access to safe drinking water (The New York Times, 2007). In addition to acute problems of water pollution in developing countries, industrialized countries continue to struggle with pollution problems as well. Most people in the developed world have flush toilets that drain sewage waste quickly and hygienically away from their homes (www.explainthatstuff.com).

Lastly, around half of all ocean pollution is caused by sewage and wastewater. Each year, the world generates 4 billion tons of industrial waste, much of which is dumped untreated into rivers, oceans and other waterways. (www.explainthatstuff.com). Improper handling of wastewater is the main reason behind the pollution of water. The sewage is drained off in large quantities into rivers. It slows down the process of dilution of the constituents present in water; which in turn, stagnates the river (www.buzzle.com). Water consumption and wastewater generation depletes outer resources and has a destructive impact on the environment. Recent attention has aimed at preserving water resources and preventing pollution through several routes. Restrictions on wastewater discharge into the environment, recycling, reuse and regeneration of wastewater streams are now common practices towards achieving these objectives.

Conclusively, the indiscriminate disposal of wastewater creates poor sanitary conditions and environmental pollution. Therefore, there is the need to alleviate most of the pressures being placed on sewage drainage, treatment and disposal systems by the increasing pollution in general using modern and proper drainage channels which will help households in no small measures, in disposing off their wastewater in such a way that will drastically reduce health hazards associated with domestic wastewater disposal in particular.

\section{Study Area and Methodology}

\subsection{Study Area}

Maiduguri urban, with a land mass of $137.356 \mathrm{Sq} \mathrm{km}$ (NPC, 2010), is located between latitude N $11^{\circ} 46^{\prime} 18^{\prime \prime}$ to N $11^{\circ} 53^{\prime} 21^{\prime \prime}$ and longitude E $13^{\circ} 03^{\prime} 23^{\prime \prime}$ to E 13 ${ }^{\circ} 14^{\prime} 19^{\prime \prime}$ (Google Earth, 2012). The area lies within the lake Chad Basin formation, which is an area formed as a result of down-warping during the Pleistocene period (Waziri, 2007). 


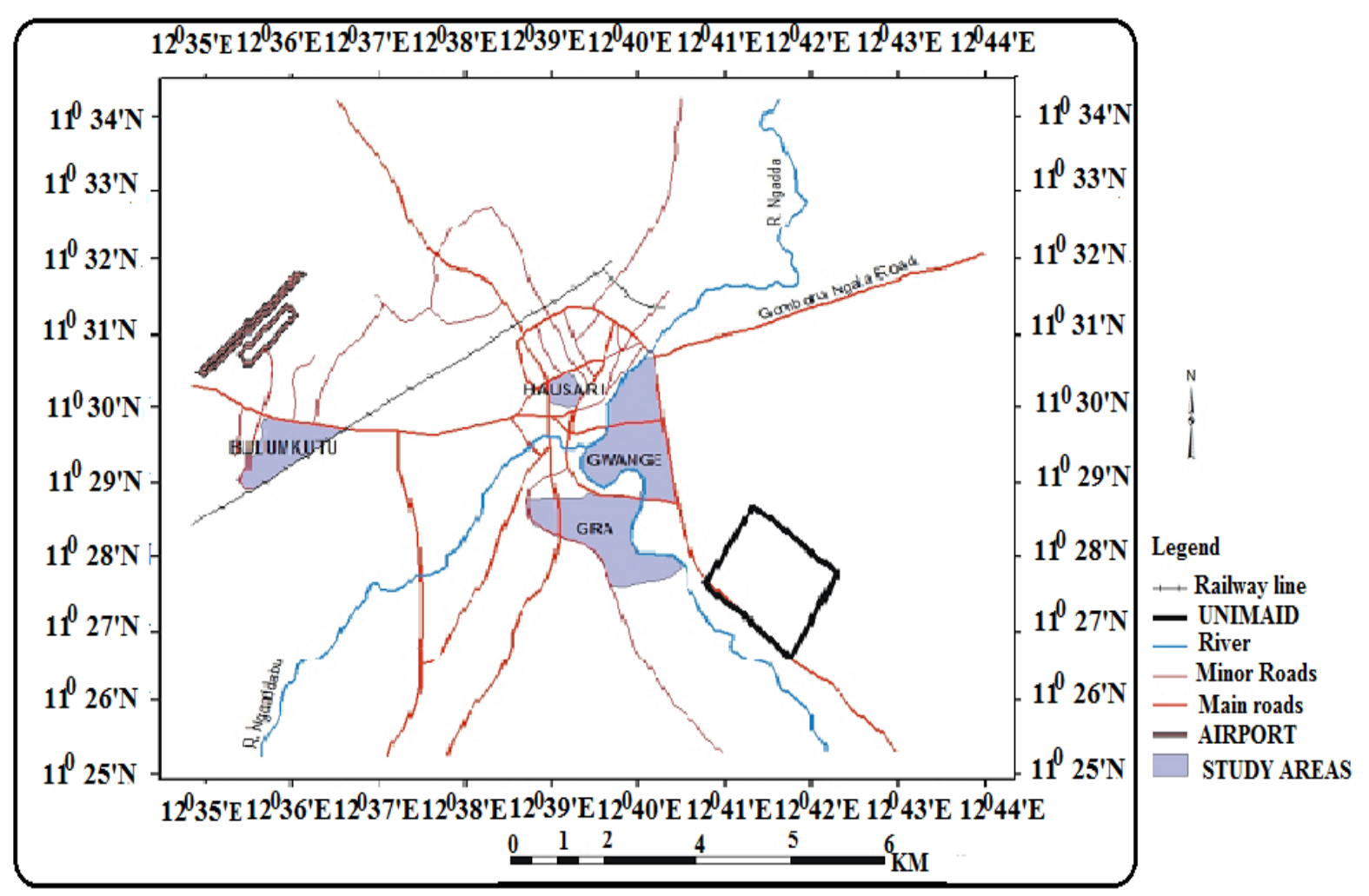

Figure 1. Maiduguri showing the study area

Source: Digitized from Google earth image, 2012.

\subsection{Methodology}

The major source of data for this study was the primary source which was used in this research. The primary data were generated through a structured questionnaire distributed to the inhabitants in the Study area. This was administered based on households, designed to capture the objectives of the study. Purposive, stratified and accidental sampling techniques were employed at different stages for obtaining data in the study area. Based on the size of Maiduguri and the number of the wards, as well as for convenience and effective management of data. Three wards were selected using purposive sampling and 120 samples each were selected from each of these wards to give a total of 360. In the selection of the required sampled household therefore, each of these wards was stratified using its major streets. For instance, in Gwange wards there were three streets, therefore 40 households were accidentally selected from each of those streets. Hausari has four streets therefore, 30 households were accidentally selected to give a total of 120 respondents while in Maisandari, 55 households were accidentally selected in GRA and 65 household were equally accidentally selected in Bulumkutu respectively. The interviewed respondents were the household heads or any adult in the household. Figure 1 shows Maiduguri Township locating the sample wards.

The data obtained from the field was analyzed using simple descriptive and inferential statistics; the simple descriptive includes Charts (histogram), frequency and percentages to compare the data that have been obtained. The inferential statistics includes analysis of variance (ANOVA) which was used to show the mean response of the resident in relation to wastewater generation and disposal in the three wards, in other to determine the variation in the wastewater generated.

\section{Results and Discussion}

\subsection{Daily Quantity of Water Used in Households in Litres}

The quantity of water use daily in a household differs from one household to another depending on the number of persons in that household and the use water is put to. Table 1 shows the responses from the residents. 
Table 1 . Daily quantity of water used in households in liters

\begin{tabular}{lcccccc}
\hline Volume in & \multicolumn{2}{c}{ Maisandari } & \multicolumn{2}{c}{ Gwange } & \multicolumn{2}{c}{ Hausari } \\
Litres/day & $\mathrm{f}$ & $\%$ & $\mathrm{~F}$ & $\%$ & $\mathrm{f}$ & $\%$ \\
\hline Bathing & & & & & & \\
$20-80$ & 23 & 19.2 & 40 & 33.3 & 41 & 34.2 \\
$81-160$ & 63 & 52.5 & 55 & 45.8 & 41 & 34.2 \\
$161-240$ & 33 & 27.5 & 19 & 15.8 & 16 & 13.3 \\
$240 \&$ above & 1 & 0.8 & 6 & 5.0 & 22 & 18.3 \\
\hline Washing & & & & & & \\
$20-80$ & 114 & 95.0 & 101 & 84.2 & 95 & 79.2 \\
$81-160$ & 19 & 15.8 & 5 & 4.2 & 13 & 10.8 \\
$161-240$ & - & - & 1 & 0.8 & 8 & 6.7 \\
$240 \&$ above & - & - & - & - & 4 & 3.3 \\
\hline Food preparation & & & & & & \\
$20-80$ & 119 & 99.2 & 116 & 967 & 109 & 90.8 \\
$81-160$ & 1 & 0.8 & 4 & 3.3 & 7 & 5.8 \\
$161-240$ & - & - & - & - & 4 & 3.3 \\
\hline Others & 118 & 98.3 & 73 & 60 & 73 & 60.8 \\
$20-80$ & 1 & 0.8 & 1 & 0.8 & 9 & 7.5 \\
$81-160$ & 1 & 0.8 & - & - & 8 & 6.7 \\
$161-240$ & - & - & - & - & 5 & 4.2 \\
$240 \&$ above & & & & & & \\
\hline 2011. & & & & & & \\
\hline
\end{tabular}

Source: Field work, 2011.

Table 1 shows the quantity of water use daily in the households. From the Table 1 therefore, most of the residents in the three wards use 81-160 litres daily per household for bathing, while 20-80 liters is being used for washing daily per household in the study area. From the table it is observed that the main uses of water which leads to high generation of wastewater in the three wards is bathing with $52.2 \%, 45.8 \%$ and $34.2 \%$ respectively. The availability of water and population of persons per household plays an important role in the volume of water to be used. If there are 5-10 persons in a family they will consume more water than the family of 4 and below. While 20-80 liters of water per day is being used for food preparation and other purposes with the percentages of $99.2 \%, 96.7 \%$ and $90.8 \%$ respectively.

\subsection{Results of Analysis of Variance (ANOVA)}

Analysis of Variance was used to show the mean responses of the residents in relation to the wastewater generation in the three wards (Gwange, Hausari and Maisandari) with a view to determine the variation in the wastewater generated. The variables for the analysis include bathing, washing, food preparation and other purposes. From the results obtained, the mean responses of the residents with regard to the wastewater generated from bathing, washing, food preparation and others, As revealed, the mean responses shows clearly that wastewater generated from bathing in Maisandari has the highest value of $2.1583^{\mathrm{a}}$ at 0.05 level of significance which implies that most of the wastewater generated from bathing in the study area comes from Maisandari. This is because, the developed part of the Maisandari (GRA) has enough water supply and uses modern facilities like showers, and other water using appliances. This might have been the reason for the increase in the rate of wastewater generation and disposal. This is in consonance with Hammer (1977) who stated that "Wastewater disposal can be influenced by quantity or volume of water discharged by a household". The volumes of wastewater from residential areas vary depending on the type of dwelling. Large flows come from family houses that have several bathrooms, washing machine and other water using appliances.

Gwange with the value $2.1000^{\mathrm{ab}}$ at 0.05 significance level comes next to Maisandari $\left(2.1583^{\mathrm{a}}\right)$. Statistically, there is no significant difference between the two. This may not be unconnected with the fact that Gwange is planned area and some of the residents either have a water storage facility or uses modern facilities. The large family size of 
most of the residents might have also contributes to wastewater generation and disposal in the area. Hausari with $1.9295^{\mathrm{b}}$ at 0.05 significance level is the least in terms of wastewater generated through bathing. This may be as a result that most of them do not use showers, having no taps and largely depend on vendors for their daily water supply; thus water being a scarce resource to them was most of the time being quantified for use.

Moreover wastewater generated from washing is high in Maisandari with the value $1.3417^{\mathrm{a}}$ at 0.05 , level of significance. This is higher than the values of Gwange $\left(1.1583^{\mathrm{b}}\right)$ and Hausari $\left(1.0583^{\mathrm{b}}\right)$ at 0.05 level of significance (though statistically, there is no significant difference between the two). In terms of wastewater generated as a result food preparation, Maisandari still has the highest value with $\left(1.1250^{\mathrm{a}}\right)$ at 0.05 significance level as compared with Gwange $\left(1.0083^{\mathrm{b}}\right)$ and Hausari $\left(1.0333^{\mathrm{b}}\right)$ at 0.05 significant levels respectively. This result therefore implies that there is no significant difference between Gwange and Hausari wards but the different exist between the two and Maisandari. Generally, wastewater generated from food preparation including washing of vegetables, meat, fish and other food products.

It equally revealed that, Maisandari $1.1250^{\mathrm{a}}$ at 0.05 significant level in terms of wastewater generated from others purposes. While Gwange with $0.5000^{\mathrm{b}}$ and Hausari with $1.1000^{\mathrm{b}}$ clearly indicated that Maisandari is the highest in terms of wastewater generation and disposal. This may not be unconnected with the fact that the availability of water in Maisandari ward encouraged high utilization of water for brushing of teeth, ablution and body cleaning after using toilet. This action contributes to large quantity of wastewater generation and disposal.

It is evident that wastewater generated in the study area was higher in Maisandari than Gwange and Hausari wards. This may likely be due to higher quantity of water supplies in that ward and the uses of modern facilities. This resultant effect is the increase in the rate of wastewater generation and disposal. This directly contributes significantly to health complications of the residents and the reduction of environmental quality.

\subsection{Sources of Water Supply}

Wastewater accumulation could only be possible if there is water supply. Figure 2 therefore shows the sources of water supply in Gwange, Hausari and Maisandari wards.

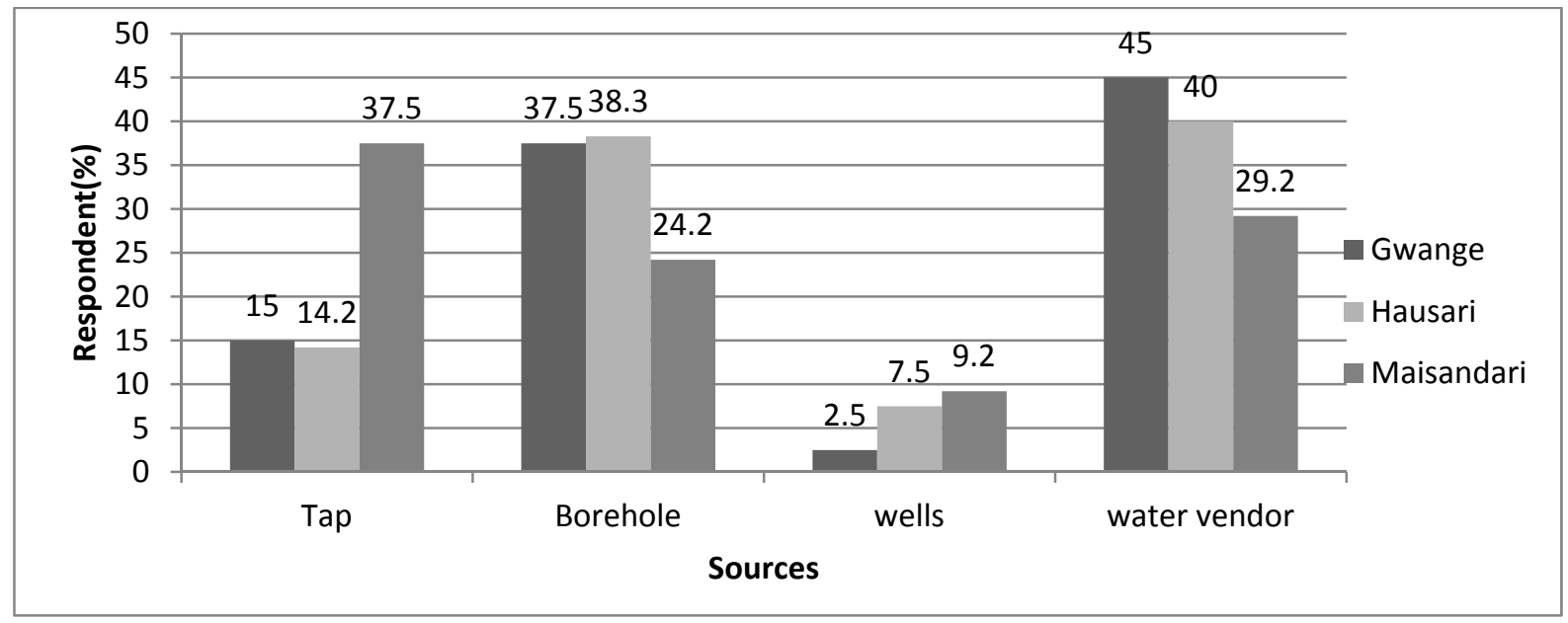

Figure 2. Sources of water supply

Source: Field work, 2011.

Figure 2 shows the major sources of water supply in the three wards of the study area. From the Figure 2 therefore, water vendor with $45 \%$ is the major source of water in Gwange, while well water with $2.5 \%$ formed the lowest in terms of source of water supply. This implies that majority of the residents depend on water vendors to supply water for livelihood. Figure 2 shows that water vendors with the highest percent $(40 \%)$ formed the major source of water supply for residents in Hausari ward, while those who source water from well $(8 \%)$ formed the lowest. In Maisandari ward, tap water (37.5\%) is the highest in terms of source and well accounted for $9 \%$. From the result therefore, it is clear that residents in both Gwange and Hausari wards largely depend on water vendors for their source of portable water supply. This may likely be as a result that for over decades, most of the boreholes and taps have stopped functioning and people of the area resorted to other alternative sources. However, in Maisandari ward, the source of their portable water supply shows a clear distinction. The ward is divided into two based on the 
settlement planning and economic status. For instance, in the Government Reservation Area (GRA) most of the residents depend on tap water (37.5\%) while in the poorly settled area such as Bulunkutu Tsallake, tap water does not exist, as such most of them depend on well and water vendors (38.4\% ) for portable water supply. This has largely affected the quantity of water the two areas used and the quantity they generate and dispose.

\subsection{Sources of Wastewater}

Wastewater generation depends on the number of people in the family; the availability of the water and the uses to which the water is put to. Figure 3 therefore, presents the sources of wastewater generated in the study area.

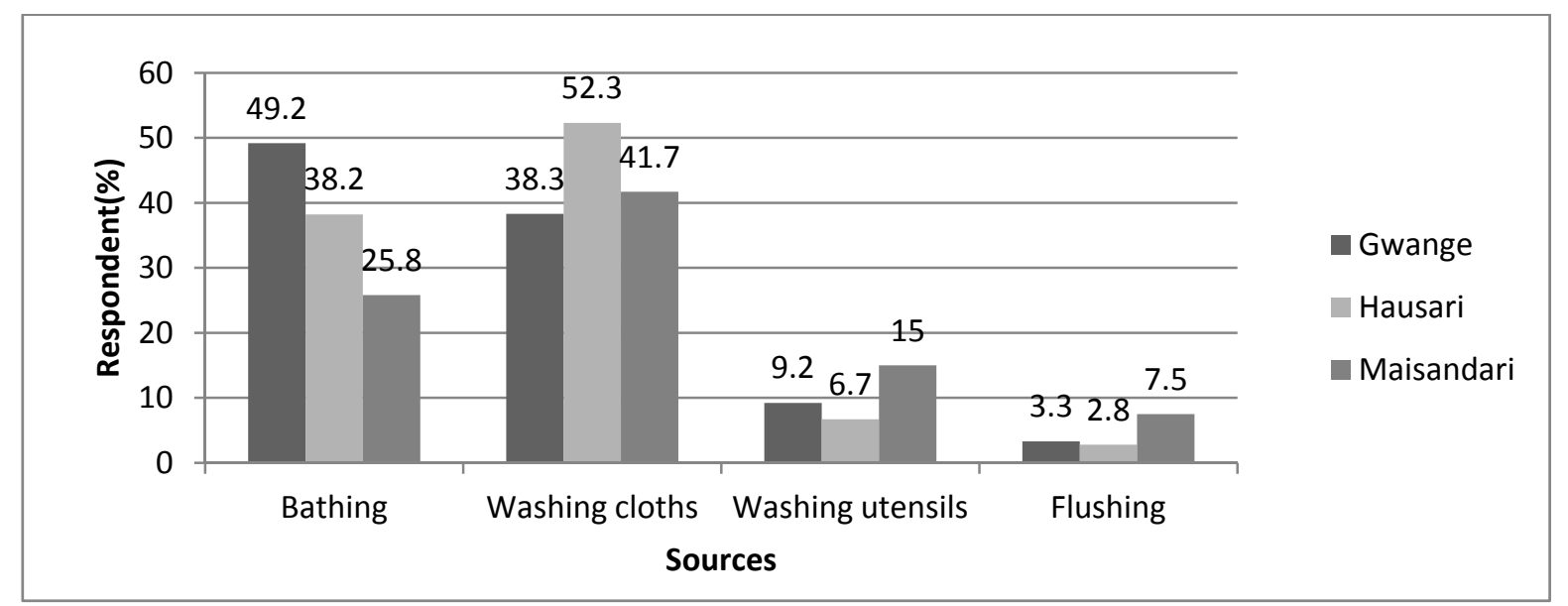

Figure 3. Sources of wastewater

Source: Field work, 2011.

From Figure 3, the main uses of water that leads to large quantity of wastewater generation and disposal in the study area are bathing with $49.2 \%$ in Gwange; washing clothes with $52.3 \%$ in Hausari; washing utensils with $15 \%$ in Maisandari and flushing toilets with 7.5\% in Maisandari respectively. This confirmed the assertion of Ghoreishi and Haghighi (2003) who were of the view that domestic wastewater is generated by the type of dwellings and commercial facilities and activities taking place. These activities/facilities include washing, bathing and other related activities. In some parts of the study area for instance, it is common among the residents of the poorly settled areas to recycle wastewater generated from some of these activities for other purposes and disposed them only when the recycled water becomes too bad for any use.

\subsection{Methods of Wastewater Disposal}

Domestic wastewater disposal varies from place to place. Figure 4 presents the methods of wastewater disposal in Gwange, Hausari and Maisandari Wards in the Maiduguri.

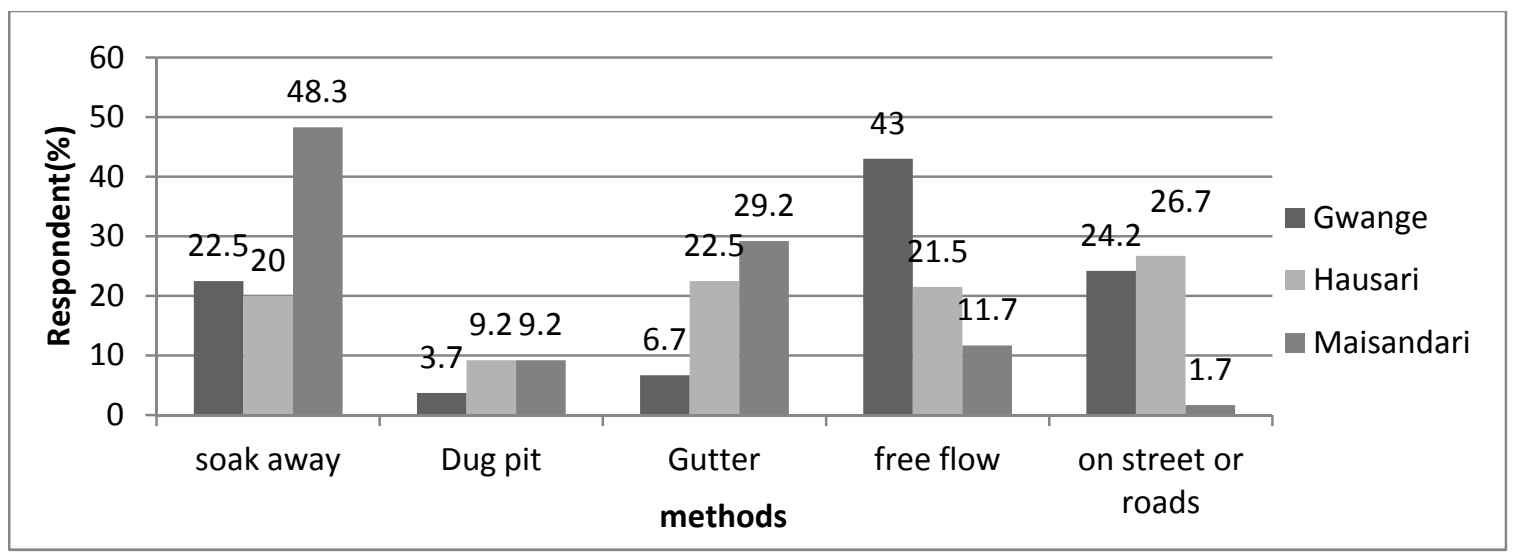

Figure 4. Methods of wastewater disposal (Source: Field work, 2011) 
From Figure 4, the most commonly used method of wastewater disposal in Gwange is through free flow with $43 \%$, in Hausari Ward the method is on street or road with $26.7 \%$. This is because there are no or poorly constructed drainage systems in the area. While Maisandari Ward most of the residents particularly those in the developed areas of Maisandari (GRA), dispose their wastewater through soak away with $48.3 \%$ while the least developed areas of Maisandari dispose theirs in Dug pit, Gutters, Free flow, and on street or road respectively. This is also due to the fact, there is no drainage or poorly constructed drainages, as the people, particularly in the least developed areas of Maisandari do not have effective channels through which wastewater generated in their houses are channeled to, whereas the developed areas of Maisandari have the efficient and effective channel through which water is emptied or disposed. Plate 1 shows a typical free flow of wastewater in Gwange ward of the study area.

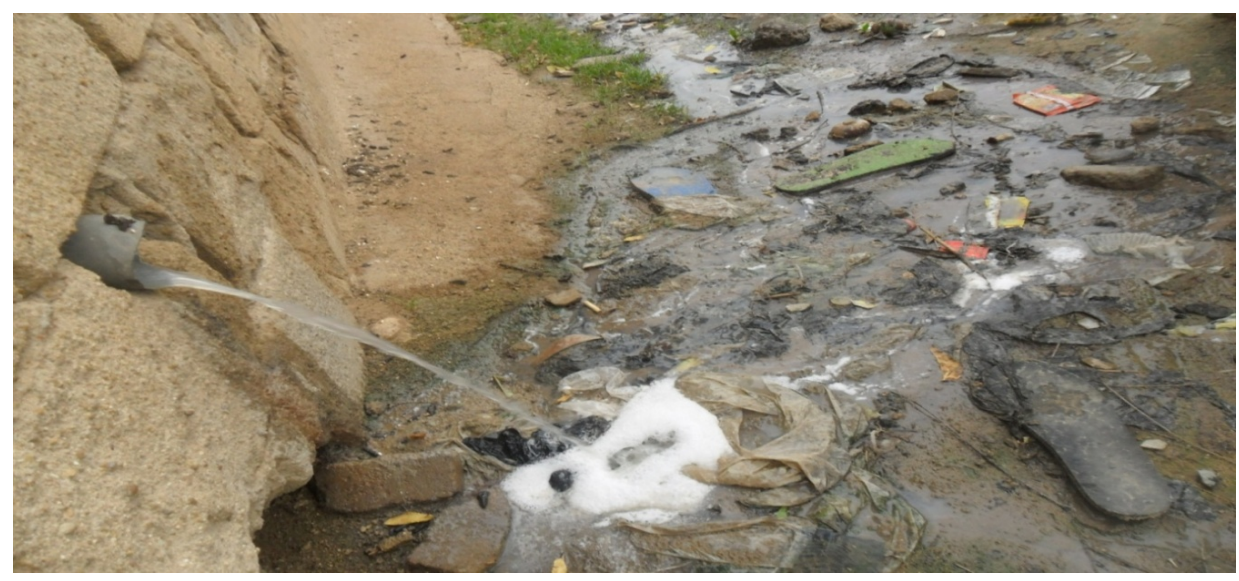

Plate 1. A typical free flow of wastewater in Gwange ward

\subsection{Drainage Problems}

The frequent generation of wastewater leads to the problems of disposal; to overcome these problems, drainage of good capacity is required and the drainage most be, free from all sorts of hindrance to serve its purpose, but reverse is the case in most places. The drainages are poorly constructed or no drainage system at all. Figure 5 shows the responses on these problems in the study area.

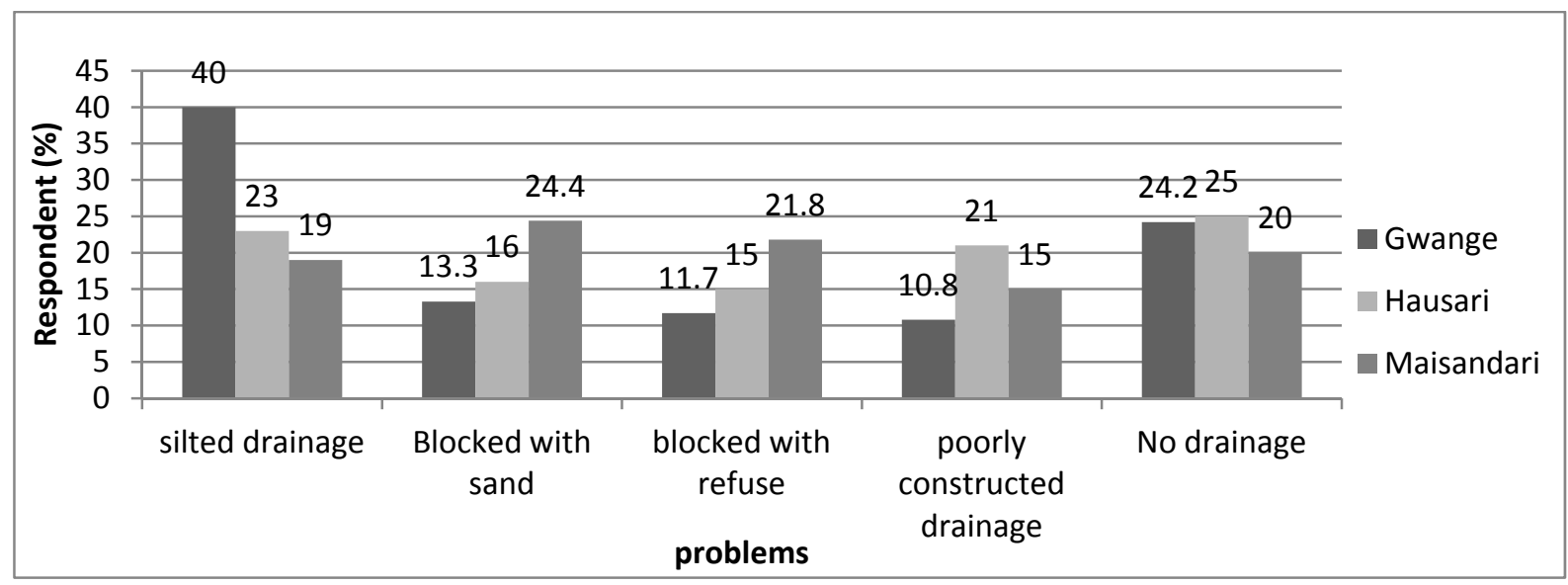

Figure 5. Drainage problems

Source: Field work, 2011.

Drainage problems faced by the residents of Gwange is caused by silted drainage (40\%), there is presence of drainage but siltation is the major problem, in Hausari ward (25\%), there are no drainage system, while Maisandari has blocked drainages $24.4 \%$ as shown in Plates 2 and 3. This is in accordance with Kodiya and Monguno (1997) 
who reported that the problem of drainage is experienced more in the urban centers due to the nature of settlements and interruptions with the natural channel resulting in the development of urban drainage system. Proper drainage management greatly helps to protect the physical environment. Indeed, an effective drainage management is an important link between man and his environment. More so the scenery of an environment depends on the nature of drainage existing in that environment and that is why any drainage problem is considered a serious environmental problem that has both spatial and temporal dimensions.

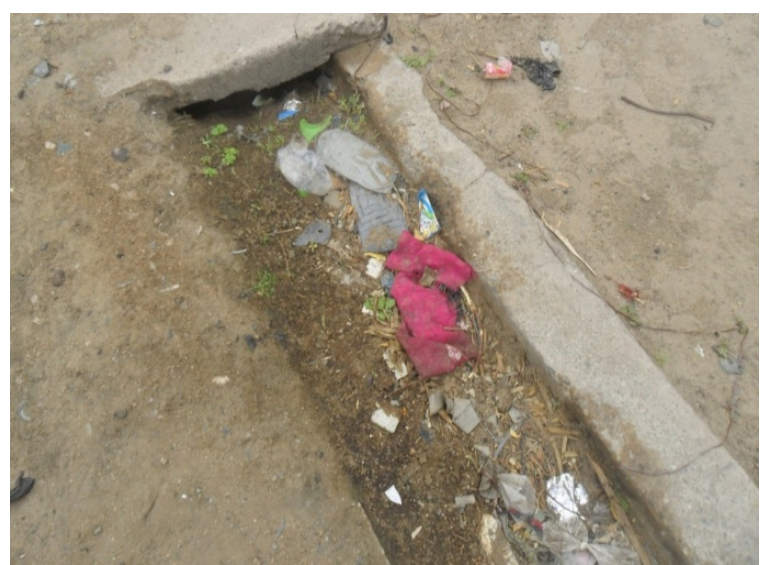

Plate 2. A typical blocked drainage with sand in Hausari

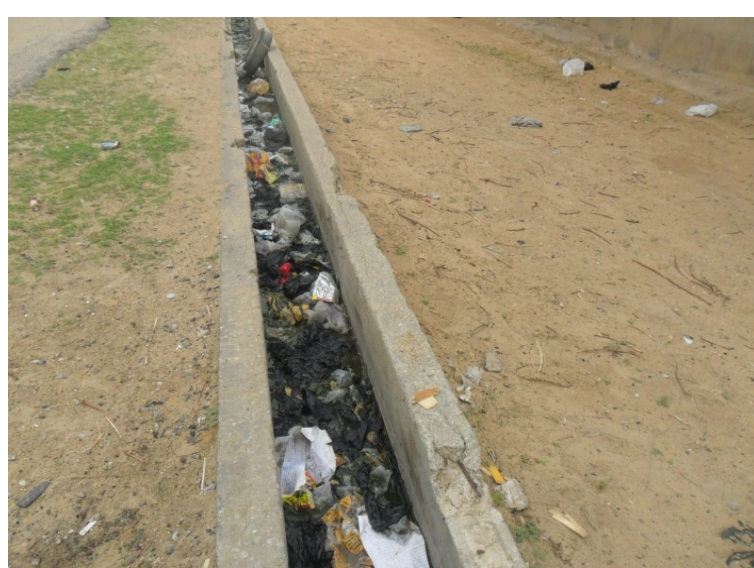

Plate 3. A typical Blocked Drainage with refuse in Maisandari

\subsection{Major Factors Affecting Wastewater Disposal}

Several factors interplay in wastewater disposal; these include population, inadequate drainages, and availability of water supply. In areas with enough water supplies having high population with less disposal facilities, wastewater is indiscriminately disposed. Figure 6 shows the responses on how population, drainage, lack of awareness and availability of water supply affects wastewater disposal.

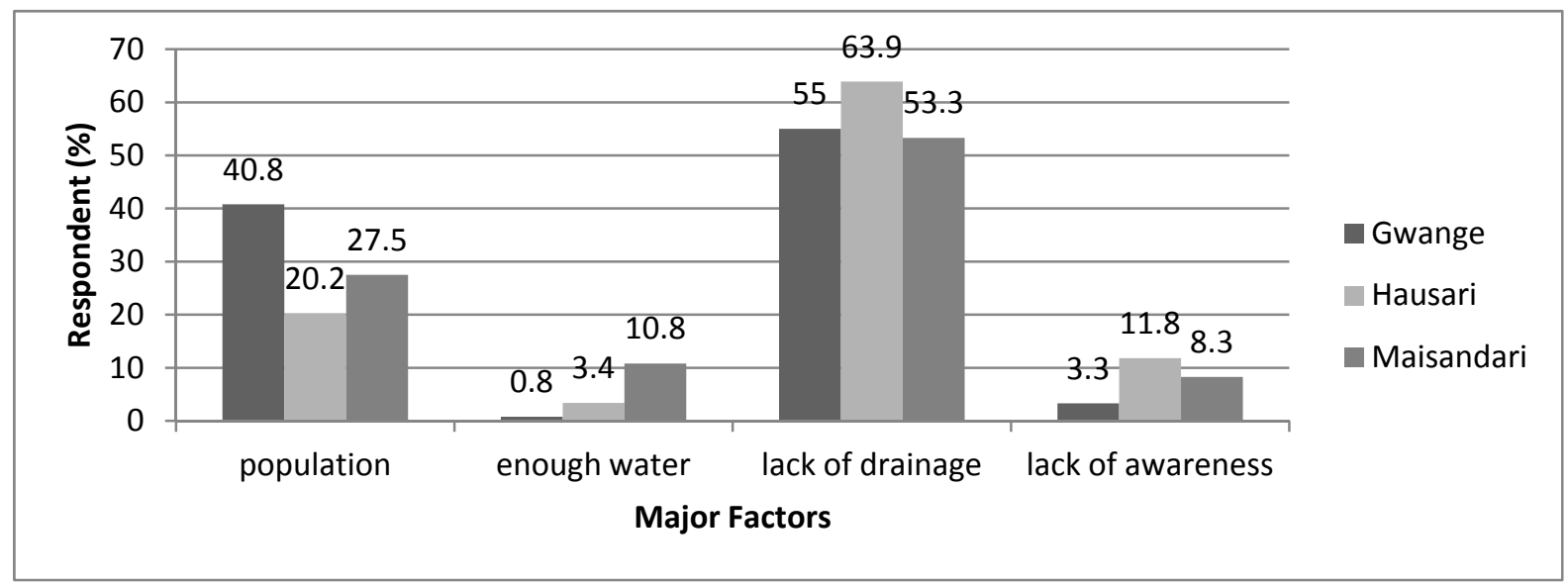

Figure 6. Major factors affecting wastewater disposal

Source: Field work, 2011.

Wastewater disposal is influenced by several factors of which some were examined in this study. Lack of drainage system and over population was observed to be the most. The aforementioned factors were seriously lamented of by the respondents in the study area as a source of concern in wastewater management. About $55.0 \%, 63.9 \%$ and $53.3 \%$ of the residents in the three wards reported that, lack of drainage is the major factor affecting wastewater disposal, while population accounted for $40.8 \%, 20.2 \%$ and $27.5 \%$ respectively. 


\subsection{Issues Due to Poor Drainage}

The problem of blocked and poorly constructed drains has so many effects on the residents. These problems include pollution, breeding of disease causing organisms, eye sore and blockage of road. Wastewater that is stagnant in the drains generate into smelly odour and serves as breeding ground for diseases. Figure 7 shows the responses on the issue of poor drainage.

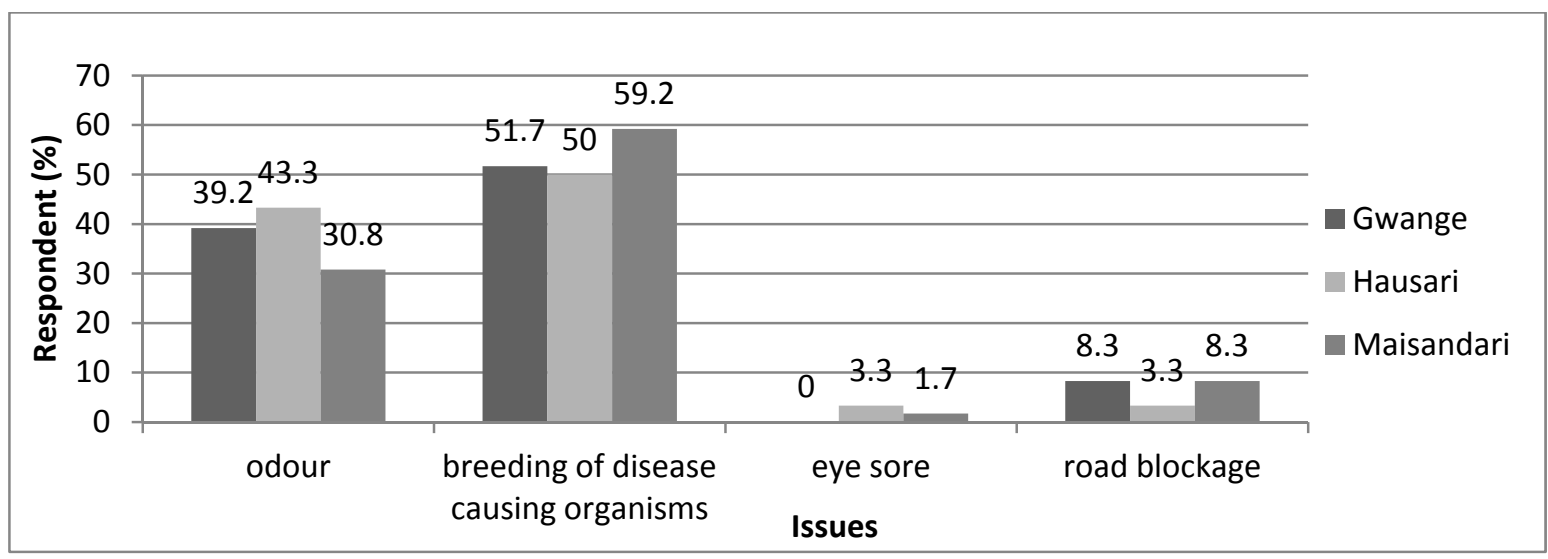

Figure 7. Issues due to poor drainage

Source: Field work, 2011.

Figure 7 presents the effects of wastewater disposal in the study area. It can be seen that breeding ground for diseases and odour are the most common effects, the percentages of breeding ground for diseases are $51.7 \%, 50 \%$ and $59 \%$, while pollution accounted for $39.2 \%, 43.3 \%$ and $30.8 \%$ respectively. In consonance with Figure 5 the various factors mentioned might have resulted into the prevalence in to the effect on both human health and the environment as shown in the Figure 5. This study confirmed the environmental studies by the UNEP (2010) which noted that, wastewater disposal is one of the main factors that encourages poor health and environmental pollution with serious consequences on human livelihood and environmental safety. Domestic wastewater usually contains certain amount of contaminants and vector-borne organisms such as disease causing bacteria, infection, viruses, parasitic organisms and other pathogens as well as toxic metals, household chemicals, and excess nutrients such as nitrates. These contaminants have negative effect on the environment, drinking water and cause health hazards to people of the study area (www.wastewaterdisposal.com).

\section{Conclusion and Recommendations}

\subsection{Conclusion}

From the findings of the study, it is evident that improper wastewater management and disposal in Maiduguri constitutes a serious hazard on human as well as the environment. Therefore, wastewater generated should be managed and disposed properly in order to avoid those hazards on the people and create a friendly and healthy environment.

\subsection{Recommendations}

Based on the findings, the following recommendations are put forward:

- Proper maintenance of the existing disposal systems by the government and individuals or the community should be done. The ministry of health in collaboration with the Borno State Sanitation Board should embark on environmental education campaign so as to create public awareness on the health implications of the improper disposal of wastewater.

- Wastewater should be flushed and drained regularly by individuals or community through weekly environmental sanitation exercise under strict supervision of the State Environmental Sanitation Board and Ministry of Health so as to help to improve the quality of the environment.

- Government should provide adequate and efficient drainage networks in all the affected areas. The design methods should be those with cover-slaps to prevent future indiscriminate dumping of refuse that are creating blockage of free flow of liquid waste. 
- Government should provide drainages in the urban areas which are channelized into a central outlet system where it can easily be treated before final disposal for other use.

- The State legislature should enact law forbidding indiscriminate dumping of waste. Defaulters should by same law be made to face severe penalties.

\section{References}

Brower, J. E., Zar, J. H., \& Ende, C. V. (1990). Field and Laboratory Method for General Ecology. W.C. Brown Publishers.

Buzzle. (2010). Sewage water pollution. Retrieved May 21, 2010, from www.buzzle.com

Chinadaily. (2005). Water Pollution in Cities. Retrieved from http://www.Chinadaily.Com.cn/English/doc/2005-06-07/content_449451.htm

Explainthatstuff. (2009). Water pollution: An introduction to cause, effects, types and solution. Retrieved May 21, 2010, from www.explainthatstuff.com

Ghoreishi, S. M., \& Haghighi, R. (2003). Chemical Catalytic Reaction and Biological Oxidation for Treatment of Non-biodegradable Textile Effluent. Chemical Engineering Journal, 95, 163-169. http://dx.doi.org/10.1016/S1385-8947(03)00100-1

Hammer, J. M. (Ed.). (1977). Water quality and pollution Waste and water technology (pp. 143-168). New York: John Wiley and Sons.

Karen, A. (2008). Environmental science. Holt, Rinechart and Winston. A Harcount education company, 1080N mopac express way building 3, Austin, Texas.

Kodiya, H. M., \& Monguno, A. K. (1997). Environmental Change and Natural Hazards in Borno. In M. M. Daura (Ed.), A Study of 1994 Maiduguri Flood. Maiduguri: Later Day Publishers.

Larry, J. A. (2002). Biology Treatment of Wastewater. West Sussex: Ellis horwood Ltd.

Mollison, K. D. (1998). Wastewater Treatment. Mac graw-hill Book.

NPC. (2007). Nation Population Commission: Population Census of the Federal Republic of Nigeria. NPC, Abuja.

Oluwande, A. P. (1971). Cheap Sewage Disposal in Developing Countries. Ibadan: Ibadan University Press.

Pink, D. H. (2006). Investing in Tomorrow's Liquid gold. Retrieved form http://finance.yahoo.com/columnist/article/trenddesk/3748

Ross, R. D. (1972). Air Pollution and Industry.

The Economist. (2008). Infrastrucure is india's biggest handicap. Retrieved December 11, 2008, from http://www.economist.com/special reports/displaystory

The New York Times. (2007). Pollution Reaches Deadly Extremes. Retrieved form http://www.nytimes.com/2007/08/26/world/asia/26china.html

UNEP. (2010). United Nations Environmental Programme. International Source book on environmentally sound technologies for wastewater and storm water management (UNEP).

Wastewater disposal. (2010). Effects of domestic wastewater disposal. Retrieved May 21, 2010, from www.wastewaterdisposal.com

Waziri, M. (2007). Trends in Population Dynamics and Implication for Contemporary Socio economic Development in the Chad Basin. Paper Presented at the Kanem Borno Millennium Conference, Maiduguri. In M. W. A. Kagu., \& K. M. Abubakar (Eds.), Issue in the Geography of Borno State.

Wikipedia. (2010). Wastewater, the free Encyclopedia. Retrieved from http://en.Wikipedia.Org/wiki/wastewater

\section{Copyrights}

Copyright for this article is retained by the author(s), with first publication rights granted to the journal.

This is an open-access article distributed under the terms and conditions of the Creative Commons Attribution license (http://creativecommons.org/licenses/by/3.0/). 